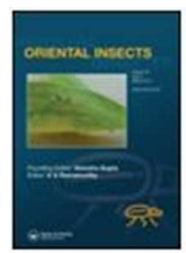

\title{
Butterfly Diversity in a Tropical Urban Habitat (Lepidoptera: Papilionoidea)
}

\begin{tabular}{|r|l|}
\hline Journal: & Oriental Insects \\
\hline Manuscript ID & TOIN-2016-0075.R2 \\
\hline Manuscript Type: & Review Article \\
\hline Date Submitted by the Author: & n/a \\
\hline Complete List of Authors: & $\begin{array}{l}\text { Chowdhury, Shawan; Dhaka University, Department of Zoology } \\
\text { Hesselberg, Thomas; University of Oxford } \\
\text { Böhm, Monika; Zoological Society of London } \\
\text { Islam, Mir; Dhaka University } \\
\text { Aich, Upama; Dhaka University }\end{array}$ \\
\hline Keywords: & $\begin{array}{l}\text { Biodiversity, Bangladesh, Conservation, Entomology, Seasonal Distribution, } \\
\text { Species Richness, Urban Ecosystems }\end{array}$ \\
\hline \multicolumn{2}{|c}{} \\
\hline
\end{tabular}

\section{SCHOLARONE ${ }^{\text {M }}$}

Manuscripts 


\section{Title- Butterfly Diversity in a Tropical Urban Habitat (Lepidoptera: Papilionoidea)}

\section{Journal Name: Oriental Insects}

3 S CHOWDHURY, T HESSELBERG, M BÖHM, M R ISLAM, U AICH

4 Key-Words: Biodiversity, Bangladesh, conservation, entomology, seasonal distribution, species richness, urban 5 ecosystems.

6 The affiliation(s) and address(es) of the author(s):

\begin{tabular}{|c|c|c|c|}
\hline Name & Affiliations and Addresses & Email Address & Contact Number \\
\hline $\begin{array}{l}\text { Shawan } \\
\text { Chowdhury }\end{array}$ & $\begin{array}{llr}\text { Department } & \text { of } & \text { Zoology, } \\
\text { University } & \text { of } & \text { Dhaka, } \\
\text { Bangladesh. } & & \end{array}$ & $\begin{array}{l}\underline{\text { shawan1094061@g }} \\
\underline{\text { mail.com }}\end{array}$ & +8801676419687 \\
\hline $\begin{array}{l}\text { Thomas } \\
\text { Hesselberg }\end{array}$ & $\begin{array}{l}\text { Department of Zoology, } \\
\text { University of Oxford, United } \\
\text { Kingdom. }\end{array}$ & $\begin{array}{l}\text { thomas.hesselberg@ } \\
\underline{\text { zoo.ox.ac.uk }}\end{array}$ & 00441865280729 \\
\hline $\begin{array}{l}\text { Monika } \\
\text { Böhm }\end{array}$ & $\begin{array}{l}\text { Institute of Zoology, Zoological } \\
\text { Society of London, Regent's } \\
\text { Park, London NW1 4RY, United } \\
\text { Kingdom. }\end{array}$ & $\begin{array}{l}\text { monika.bohm@ioz.a } \\
\underline{\text { c.uk }}\end{array}$ & $+44(0) 2074496676$ \\
\hline $\begin{array}{l}\text { Mir } \\
\text { Raihanul } \\
\text { Islam }\end{array}$ & $\begin{array}{l}\text { Institute of Statistical Research } \\
\text { and Training, University of } \\
\text { Dhaka, Bangladesh. }\end{array}$ & rislam1@,isrt.ac.bd & +8801675100012 \\
\hline $\begin{array}{l}\text { Upama } \\
\text { Aich }\end{array}$ & $\begin{array}{llr}\text { Department } & \text { of } & \text { Zoology, } \\
\text { University } & \text { of } & \text { Dhaka, } \\
\text { Bangladesh. } & & \end{array}$ & $\begin{array}{l}\text { aich.aich49@gmail.c } \\
\underline{\text { om }}\end{array}$ & +8801681858521 \\
\hline
\end{tabular}

The e-mail address and telephone number of the corresponding author:

\begin{tabular}{|l|l|l|l|}
\hline Name & Postal Address & Email Address & Contact Number \\
\hline Shawan Chowdhury & $20 \mathrm{D} / \mathrm{A}, 1^{\text {st }}$ Colony, & shawan1094061@gmail.com & +8801676419687 \\
& Mazar Road, & & \\
& Mirpur-1, Dhaka- & & \\
& 1216. & & \\
\hline
\end{tabular}

Acknowledgments

9 The authors are grateful to Author AID, Prof. Dr. Abul Hasan, Muzammel Hossain and Kawsar 10 Khan. 


\section{Abstract}

Butterflies are important pollinators and indicators of environmental health. Habitat destruction and fragmentation caused by developmental activities and poor natural resource management are the main reasons for the drastic decline of butterfly populations throughout the world, and prompt the need for effective conservation management. We assessed the diversity, richness, seasonal distribution and conservation priorities of butterflies in an inner-city parkland habitat (University of Dhaka, Bangladesh) and investigated the biotic, and abiotic factors affecting butterfly diversity. A total of 93 species from 5 families were recorded from January to December 2014. Nymphalidae and Papilionidae were the most and least dominant families in terms of species number. Butterflies across families generally selected nectar plants randomly, although some showed preference towards herbs. Spatial interpolation of butterfly richness indicated that the most suitable area was around Curzon Hall, an area containing different types of vegetation. Precipitation was the only abiotic factor with a significant relationship with butterfly species richness. The establishment of green areas with complex structural vegetation will improve microclimatic conditions for butterflies, promoting healthier urban ecosystems, and the conservation of butterflies and other associated species in inner-city areas.

27 Key-Words: Biodiversity, Bangladesh, conservation, entomology, seasonal distribution, 28 species richness, urban ecosystems. 
30

31

32

\section{Introduction}

Over the past few decades, the maintenance of biological diversity has become an issue of both local and global concern, with biodiversity declines continuing unabated despite international biodiversity targets such as the Convention on Biological Diversity's Aichi Targets aiming to reduce biodiversity loss (Tittensor et al. 2014; Butchart et al. 2010). Tropical ecosystems are particularly affected by biodiversity loss, since they are high in species diversity and abundance while pressures affecting species are often most pronounced (Collen et al. 2008). Habitat loss through agricultural conversion of land and urbanisation are the main factors driving species towards extinction (e.g., Schipper et al. 2008; Böhm et al. 2013). Rates of urbanization have increased faster in tropical regions than the rest of the world, from $30.5 \%$ in 1980 to $45 \%$ in 2010 (Edelman et al. 2014). Yet urban areas are not devoid of biodiversity and are subject to the same factors affecting ecosystems elsewhere, i.e. climate, substrate, resident biodiversity, and topography (Pickett et al. 2011). Retaining, establishing and effectively managing urban ecosystems can aid the conservation of biodiversity and increase public well-being (Chong et al. 2014).

The compilation of species lists and identification of habitat preferences, and abundances are the first steps in effectively conserving biodiversity through the establishment of species baselines and basic ecological requirements. Insects are the most diverse group of animals making up around $90 \%$ of the total animal species (Glenner et al. 2006; Scheffers et al. 2012), yet for most tropical insect groups, we know almost nothing about their ecology, distribution and abundance. Butterflies (Lepidoptera: Rhopalocera) are important pollinators (Proctor et al. 1996; Amin et al. 2015; Rader et al. 2016) and are indicators of environmental health due to their sensitivity to climatic and other abiotic factors (such as temperature, precipitation, humidity and 
53 light levels) and anthropogenic pressures (such as habitat fragmentation, pesticides and 54 pollution) (Clausen et al. 2001; Fleishman et al. 2009; van der Putten et al. 2010; Stefanescu et 55 al. 2004). Butterflies rely on host plants interactions for the completion of their lifecycles, often 56 rendering them highly habitat-specific and their abundance season-specific (Bernays \& Chapman 57 2007; Awmack \& Leather 2002). Additionally, their aesthetic value makes them popular among 58 amateur naturalists and collectors. As a result, they are a relatively well studied group throughout 59 the world, especially in temperate regions, where they are regularly used to monitor 60 environmental changes (Thomas 2005; New 1997). However, significant data gaps remain, 61 specifically in tropical regions (Lewis \& Senior 2011).

62 Habitat loss is a very common result of urbanization which together with habitat 63 fragmentation, can cause drastic reduction in species diversity. Changes in habitat quality might 64 be manifested as altered host plant quality, microclimate, predation risk, or soil attributes 65 (McKinney 2002; Rickman \& Connor 2003). Factors such as presence of pesticides, changes in 66 light and nutrients, air pollution, soil compaction, water regimes and exotic species also 67 contribute to changes in habitat quality.

68 Changes in habitat quality caused by urbanization might alter insect richness, resulting either 69 in decreases, or more rarely in increases, in the richness of specific insect groups (McKinney 70 2008). Insects, such as butterflies, which are found in both rural and urban habitats, diversity and 71 richness is much lower in urban areas than in natural ones (Raupp et al. 2010). However, the 72 density of individual herbivores, and thus the resultant damage on the host plant, can be much 73 higher in the urban setting (McIntyre 2000). Higher densities of herbivorous insects in urban 74 areas might arise for two reasons: i) as a result of the stresses on the urban plants by soil 75 compaction, air pollution, temperature and water imbalances, which makes plants specially prone 
76 to insect attack, or ii) because the population numbers of the natural enemies of herbivores are

77 often lower in urban areas (Connor et al. 2002). In addition, in some cases, exotic plants serve as

78 alternative hosts for some insect species which support greater populations than in original 79 habitats, again increasing pressures on natural host plants (Agrawal et al. 2006; Graves \& 80 Shapiro 2003; Shapiro 2002).

81 Larsen (2004) documented around 236 species of butterfly in Bangladesh. Additional species 82 have been discovered since (Bashar 2014; Chowdhury \& Hossain 2013; Chowdhury et al. 2016) 83 and a number of recent ecological studies have focused on butterflies in Bangladesh (Chowdhury 84 et al. 2014; Khan 2014; Khandokar et al. 2013). However, only limited work has been carried out 85 to link the diversity of butterfly species to the associated plants and wider ecology (Bashar et al. 86 2006).

87 Here, we provide an initial baseline for butterfly diversity in a tropical urban setting in Dhaka, 88 Bangladesh. We investigated diversity and seasonal distribution of butterflies in relation to biotic 89 and abiotic factors in an inner city environment where habitats are under great pressure from 90 human impact, such as pollution and urban development. Dhaka, a city of 17 million inhabitants, 91 is the capital of Bangladesh and suitable habitats for wildlife are scarce with the few existing 92 areas under serious threat. We investigated important butterfly-plant associations and develop 93 recommendations of how butterfly conservation and monitoring can be supported in an urban 94 tropical environment based on our findings. 
98 This study was carried out at the University of Dhaka campus which is situated at the center of 99 the capital of Bangladesh $\left(23.73^{\circ} \mathrm{N}\right.$ and $\left.90.39^{\circ} \mathrm{E}\right)$. Having more than 115000 people per square 100 kilometer, Dhaka is one of the most populated cities in the world, and experiences much urban 101 development and pollution. However, the University of Dhaka campus is relatively undisturbed, 102 with a number of vegetation layers including canopy, shrubs and herbs which could sustain 103 relatively high levels of biodiversity. There are numbers of water resources in the University of 104 Dhaka campus which have made this campus as a sound habitat for butterfly populations.

Figure 1. Map of the University of Dhaka campus (Adapted from a map, created by Department 107 of Geography, University of Dhaka)

\section{Butterfly Surveys}

110 Surveys were carried out multiple times per week from the $1^{\text {st }}$ of January 2014 to the $31^{\text {st }}$ of 111 December 2014. During the survey, paths taken were carefully chosen through campus on a 112 given day in such a way that the entire campus was covered each week indeed no surveys were 113 carried out when it rained. Each survey took about two hours and covered approximately $1 \mathrm{~km}^{2}$. 114 Surveys were conducted between early morning and late afternoon by the first author. To avoid 115 biasness, the direction of survey area was changed periodically. All butterflies visible from the 116 path were recorded. In this study, two different cameras (Sony DSC W560 Cybershot and Canon 117 Powershot SX 510HS) were used to take photographs in order to aid identification of butterflies 118 to species level along each survey path, using a number of published resources (Ek-Amnuay \& 119 Komaradat 2012; Kehimkar 2008; Chowdhury \& Hossain 2013; Bashar 2014). Collections were 
120 restricted to those species which could not be identified properly by using the above method. In 121 these cases, butterflies were collected using sweep nets. Each specimen was placed in a plastic 122 bottle and taken to the laboratory for identification. As the activity and species richness of 123 butterflies are known to depend on both time of day and season of the year (Harvell et al. 2002; 124 Stefanescu et al. 2004; Forister et al. 2010). We summarized total observed species richness per 125 week for consistency.

126 We studied the influence of abiotic factors on butterfly species richness by including relative 127 humidity $(\%)$, temperature $\left({ }^{\circ} \mathrm{C}\right)$ and precipitation $(\mathrm{mm})$ into our analysis. Data for these factors 128 were obtained from a meteorological website (wunderground.com). We considered weekly data 129 for the analysis to reflect our weekly aggregates of butterfly species richness. We also collated 130 the national-level conservation status (Not Assessed (NA), Least Concern (LC), Near Threatened 131 (NT), Vulnerable (VU), Endangered (EN), and Critically Endangered (CR)) of recorded species 132 from the recent publication of the Bangladesh National Red List for butterflies (IUCN 133 Bangladesh 2015). Statistical analyses were carried out using R (version 3.3.0) (R Core Team 134 2014) and the significance level was set at 5\%.

\section{Butterfly Richness and Plant Associations}

136 Butterflies plant activities were recorded nectar collecting or visits to flowers were observed. 137 In this study, we observed few butterfly associated plants in which they were being mostly 138 observed, collecting nectar, roosting or other showing other features. We categorized different 139 associated plant species into herbs, shrubs and trees and analyzed them with a one-way ANOVA.

140 The effect of environmental variables on butterfly diversity was analysed with general linear 141 models (LM) with species richness as response variable and temperature, precipitation and 
142 humidity as explanatory variables. Initial models were simplified by removing non-significant 143 terms following the marginality rule (Pekar \& Brabec 2016). The models generated were tested 144 for violations to the 5 model assumptions (normality of residuals, homoscedasticity of residuals, 145 collinearity, serial autocorrelation and bias from influential observations based on Cook 146 distances) following recommendations by Thomas et al. (2013) and met all assumptions except 147 from some evidence of autocorrelation.

\section{Spatial Prediction of Butterfly Species Richness}

149 We used spatial interpolation to map the predicted occurrence of butterflies across the University 150 of Dhaka campus. Spatial interpolation is the prediction of values of attributes at unsampled 151 locations $\mathrm{S}_{0}$ from existing measurements at $\left(\mathrm{s}_{1}, \ldots, \mathrm{s}_{\mathrm{n}}\right)$. This procedure converts a sample of point 152 observations into an alternative representation such as a contour map or grid. Deterministic 153 interpolation techniques create surfaces from measured points based on either the extent of 154 similarity or degree of smoothing. In this study, we used inverse distance weight (IDW) 155 interpolation to smooth data.

156 The IDW algorithm is a moving average interpolator that is usually applied to highly variable 157 data ( $\mathrm{Lu} \&$ Wong 2008). For example, for certain data types it is possible to return to the 158 collection site and record a new value that is statistically different from the original reading but 159 within the general trend for the area. The IDW technique calculates a value for each grid node by 160 examining surrounding data points that lie within a user-defined search radius. It implements the 161 assumption that things that are close to one another are more alike than those that are farther 162 apart. To predict a value for any unmeasured location, IDW will use the measured values 
163 surrounding the prediction location. Thus it assumes that each measured point has a local 164 influence that diminishes with distance.

165

166 It computes one such weighted average:

$$
T\left(s_{0}\right)=\sum_{i=1}^{n} w_{i 0} Y\left(s_{i}\right)
$$

167 where $Y\left(s_{i}\right)$ is the richness of the butterflies at location $s_{i}$ and weights $w_{i j}$ are determined 168 according to the distance between points $s_{i}$ and $s_{j}$, and scaled by parameter қ:

$$
w_{i j}=\frac{1}{h_{i j}^{\mathrm{K}}} w i t h h_{i j}=\left\|s_{i}-s_{j}\right\|
$$

169 Values of $қ>1$ reduce the relative impact of distant points and produce a fluctuating map and 170 values of $\mathrm{k}_{\mathrm{V}}<1$ increase the impact of distant points and produce a smooth map.

\section{Results}

173 Over the study period, we observed 93 species of butterflies belonging to 62 genera and five 174 families (see table S1 in the supplementary information). Among those five families, the most 175 abundant family was Nymphalidae for which we recorded 27 species; Papilionidae was the least 176 abundant family, with 7 species. The other recorded families were Lycaenidae (26 species), 177 Hesperiidae (19 species) and Pieridae (13 species). Overall, recorded species richness was 178 highest in week 22 (May, 51 species observed) with a second peak in week 51 (December), with 
179 lowest species richness recorded in week 40 (July, only 28 species observed) (Figure 2). Of the 180 butterfly species recorded, 26 are reported as nationally threatened (see supplementary 181 information). Some of the most species-rich families on campus also showed high proportions of 182 threatened species being recorded, namely 47\% (9 out of 19 species) for Hesperiidae and $35 \%$ ( 9 183 out of 26 species) for Lycaenidae. The remaining eight threatened species belong to the 184 Nymphalidae (6 out of 27 species) and Pieridae and Papilionidae (one species each).

Figure 2. Weekly butterfly species richness at the University of Dhaka campus throughout the 187 study period.

Butterfly species richness had a negative relationship with temperature, precipitation and 190 humidity (Fig. 3; LM, F(5,46) =5.28, $\mathrm{P}<0.001$, Adjusted $\mathrm{R}^{2}=0.30$ ). However, only the main 191 effect of precipitation was significant $(\mathrm{LM}, \mathrm{t}=3.25, \mathrm{P}=0.002)$, whereas temperature $(\mathrm{LM}, \mathrm{t}=$ 192 1.91, $\mathrm{P}=0.06)$ and humidity $(\mathrm{LM}, \mathrm{t}=1.92, \mathrm{P}=0.06)$ were not significant. In addition, 193 interactions between temperature and humidity $(\mathrm{LM}, \mathrm{t}=7.90, \mathrm{P}=0.007)$ and precipitation and 194 humidity $(\mathrm{LM}, \mathrm{t}=10.31, \mathrm{P}=0.002)$ were significant.

196 Figure 3. The relationship of abiotic factors to butterfly species richness: a. Average 197 Temperature vs. Species Richness; b. Average Precipitation vs. Species Richness and c. Average 198 Humidity vs. Species Richness. 
200 There was no statistically significant relationship between different vegetation types and 201 butterfly families (One-way ANOVA, $\mathrm{F}_{12}=0.38, \mathrm{P}=0.86$ ).

202 The inverse distance interpolation of the predicted species richness of the families of 203 butterflies around the University of Dhaka campus along with their actual richness indicate that 204 butterflies were mostly active in the Curzon Hall area of University of Dhaka campus.

206 Figure 4. Map of the University of Dhaka campus showing measured (a) and predicted (b) 207 species richness of butterflies using the inverse distance weight interpolation.

\section{Discussion}

210 During our study, some of the most common butterfly species (such as Euchrysops cnejus, 211 Chilasa clytia and Papilio polytes) were spotted almost during every survey. This may indicate 212 that the species breed locally (although it is conceivable that strong fliers such as Papilio clytia 213 and Papilio polytes may breed elsewhere), which suggests that the food plants of these butterflies 214 are present in our study area and that their caterpillars are tolerant of this particular habitat. Other 215 butterflies (such as, Leptotes plinius, Papilio polymnestor and Delias pasithoe etc), despite 216 generally known to feed on common plant species, were hardly observed during the 12 months 217 study period, suggesting that these are irregular visitors to the study area, most likely due to a 218 lack of appropriate habitat for these species which would otherwise support breeding 219 populations. Specifically, some of these rare butterflies are likely to be migrants and the larval 220 food plants may therefore not be present at the study site (Goehring \& Oberhauser 2002): either 
221 the larval host plants were never present in the study area or have been lost following habitat loss 222 due to urbanization and modification of the University of Dhaka campus. The richness and 223 distribution of butterfly species also fluctuates in accordance to their life cycle which is tied to 224 seasonal changes. However, compared to temperate butterflies, seasonal variation does not 225 typically have a large impact on tropical butterflies which remains well distributed throughout 226 the year, particularly in areas without a pronounced dry season (Hamer et al. 2005). In 227 Bangladesh, where the pronounced dry season lasts from November to May, we observed 228 fluctuations in the number of butterfly species at different times of the year (Figure 2). 229 Butterflies of the University of Dhaka campus showed highest species richness in the dry season 230 with $\%$ of the total species observed during this period. This finding is contrary to that of other 231 studies, which report higher numbers in the rainy season (Hamer et al. 2005; DeVries et al. 232 1997). A possible explanation for this is that human intervention in the form of watering 233 provides more food resources for butterflies on the campus than in surrounding areas and as such 234 attracts a higher than usual number of butterflies during the dry season.

235 A high number of nationally-threatened (though often globally common) species were 236 recorded on the University of Dhaka campus. While many of these were recorded as rare or very 237 rare (such as, Anthene lycaenina, Tarucus nara and Tarucus callinara) in our study, some were 238 actually common or fairly common (such as, Catochrysops strabo, Spalgis epius and Suastus 239 gremius). This suggests that urban areas, despite the presence of anthropogenic pressures, can 240 provide important habitats for threatened species. Previous research has shown that urban 241 artificial or semi-artificial habitat can play an important role in the conservation of threatened 242 species (e.g. Reeder et al. 2015; Recuero et al. 2010). Management of vegetation should 243 therefore take into account the needs of threatened and non-threatened species alike. 
244 Previous studies have shown that the diversity of butterflies greatly depends on the 245 availability of food plants (e.g., Burghardt et al. 2009; Ricketts 2002). From the observation of 246 nectar-feeding in this study, Rubiaceae and Verbenaceae were the most preferred plant families 247 for Pieridae; Asteriaceae for Lycaenidae; Amaranthaceae and Asteriaceae for Nymphalidae; 248 Asteriaceae and Rubiaceae for Hesperiidae and Rubiaceae for Papillionidae. All five families of 249 butterflies collected nectar from plants of the Rubiaceae family, whereas, only a few nymphalids 250 were observed collecting nectar from the Phyllantaceae, Smilacaceae, Anacardiaceae, Urtiaceae 251 and Moraceae. Our results suggest that active management to promote Rubiaceae species, with 252 additional management for Asteriaceae and Poaceae species (the latter specifically for Satyrid 253 species) is likely to maintain current adult butterfly populations at the University of Dhaka 254 campus. In addition, further studies on larval host plants are required to ensure that breeding 255 populations of butterflies are retained in this urban setting.

256 Satyrid butterflies were mostly active in the drier parts of the year and they were spotted in 257 the more shaded areas. These patterns may be explained by the differences in the usage of 258 microhabitats by species in different taxa; species of satyrid butterflies have a strong preference 259 for dense shade at ground level (Hamer et al. 2003; Hill et al. 2001) and those observed in this 260 study, were mostly found on shade tolerant grasses and bamboos (Poaceae) (Robinson et al. 261 2001). As a result, it is vital to maintain habitat which provides a range of microclimate and 262 shade levels to the resident species of butterfly.

263 Any associations between butterfly species richness and different abiotic factors in this study 264 were found to be largely insignificant. We found that only precipitation and the interaction of 265 humidity with temperature and precipitation influenced butterfly species richness. As this study 
266 only collected data over the period of a single year, more extensive study is required to account 267 for variation in climatic factors between years.

268 Different vegetation management methods and modes are used on rights-of-way (Smallidge et 269 al. 1996), relying on site limitations and environmental and economic constraints. With the help 270 of experts from different sectors including vegetation management and landscape ecology 271 experts, the habitat needs of butterflies can be integrated. Depending on the life-cycle of the 272 butterfly and the regeneration requirements of the host plants, management activities can be 273 increased in frequency, intensity, or magnitude to create favorable regeneration conditions 274 without jeopardizing butterfly population (Smallidge et al. 1996).

275 Compared to the other areas of the University of Dhaka campus, the area around Curzon Hall 276 is comprised of different types of vegetation. Interestingly, butterflies of different families were 277 observed displaying a range of behaviors, such as resting, feeding and courtship etc. This 278 suggests that this area is suitable for accommodating resident butterfly populations for a cross279 section of species. Our species interpolation map showed that the diversity and richness of 280 butterflies peaked in the Curzon Hall area, with very low occurrences recorded in other areas. 281 Better management of habitat and reduction of habitat destruction, human interference and 282 pollution by visitors and students is essential for the conservation of wider areas of the campus 283 for butterflies.

284 In order to conserve butterflies in a tropical urban area such as the University of Dhaka 285 campus specific measures must be taken. Conserving different micro-habitats and vegetation 286 layer complexity, reducing habitat fragmentation and preventing man-made pollution as much as 287 possible, and keeping adequate humidity levels during periods of adverse weather will help 
288 butterflies to colonize the area. In addition, planting nectar plants of different plant families will 289 also help to attract butterflies. It is not certain whether adult butterflies remain in the same micro290 habitats where immature stages are concentrated, so suitable resource conditions for both 291 immature and adult stages are necessary to maintain butterfly populations. This also includes 292 management and establishment of a vegetation corridor for the movement of butterflies across 293 campus, including butterfly gardens providing feeding opportunities from plants and fruit.

294 Continuing population maintenance is a dynamic process. Dynamic systems require constant 295 attention and monitoring (Sibatani 1990). As our current study was only conducted during one 296 year, additional monitoring is required to establish trends in butterflies over time. Specifically, if 297 management for butterfly diversity is introduced in the area, monitoring is needed to establish if 298 management has the desired outcome for species richness and abundance. Often, resources are 299 scarce to carry out such monitoring. However, citizen science is becoming a cornerstone of 300 biodiversity monitoring throughout the world (e.g. Proenca et al. 2016) and butterflies as a 301 charismatic insect taxon lend themselves to such monitoring schemes. Especially in urban 302 landscapes, citizen science may be very effective due to a large pool of potential volunteers 303 (Matteson et al. 2012). Development of a standard monitoring protocol, to be carried out at 304 specific times throughout the year (our data suggests that November to May may be most 305 suitable), is essential, as is securing sufficient volunteers, including students, for the anticipated 306 monitoring effort. In addition, citizen science provides direct conservation engagement and 307 education to city-dwellers and the scheme can relatively easily be expanded to other areas within 308 the green zone of Dhaka (and other tropical urban areas). 
310

311

312

313

314

315

316

317

318

319

320

321

322

323

324

325

326

327

328

329

330

331

\section{References}

Agrawal AA, Lau JA, Hambäck PA. 2006. Community heterogeneity and the evolution of interactions between plants and insect herbivores. The Quarterly Review of Biology. $81: 349-376$.

Amin MR, Namni S, Miah MRU, Miah MG, Zakaria M, Suh SJ, Kwon YJ. 2015. Insect inventories in a mango-based agroforestry area in Bangladesh: foraging behavior and performance of pollinators on fruit set. Entomological Research. 45:217-224.

Awmack CS, Leather SR. 2002. Host plant quality and fecundity in herbivorous insects. Annual review of entomology. 47:817-844.

Bashar MA. 2014. Butterflies of Bangladesh (A Wide Approach to Nature Lovers). BCTF Publications.

Bashar MA, Mamun MA, Aslam AFM, Chowdhury AK. 2006. Biodiversity maintenance and conservation of butterfly-plant association in some forests of Bangladesh. Bangladesh Journal of Zoology. 34:55-67. 
332 Böhm M, Collen B, Baillie JE, et al. 2013. The conservation status of the world's reptiles. 333 Biological Conservation. 157:372-385.

334

Burghardt KT, Douglas WT, Gregory SW. 2009. Impact of native plants on bird and butterfly biodiversity in suburban landscapes. Conservation Biology. 23:219-224.

Butchart SH, Walpole M, Collen B, van Strien A, Scharlemann JP, Almond RE, Baillie JE, Bomhard B, Brown C, Bruno J, Carpenter KE. 2010. Global biodiversity: indicators of recent declines. Science. 328:1164-1168.

Chong KY, Teo S, Kurukulasuriya B, Chung YF, Rajathurai S, Tan HTW. 2014. Not all green is 343 as good: Different effects of the natural and cultivated components of urban vegetation on $344 \quad$ bird and butterfly diversity. Biological Conservation. 171:299-309.

352 Chowdhury SH, Hossain M. 2013. Butterflies of Bangladesh-A Pictorial Handbook (Revised and 353 enlarged version I). Skylark Printers. 
355 Clausen HD, Holbeck HB, Reddersen J. 2001. Factors influencing abundance of butterflies and 356 burnet moths in the uncultivated habitats of an organic farm in Denmark. Biological 357 Conservation. 98:167-178.

358

359 Collen B, Ram M, Zamin T, Mcrae L. 2008. The tropical biodiversity data gap: addressing 360 disparity in global monitoring. Tropical Conservation Science. 1:97-110.

361

362 Connor EF, Hafernik J, Levy J, Moore VL, Rickman JK. 2002. Insect conservation in an urban 363 biodiversity hotspot: the San Francisco Bay Area. Journal of Insect Conservation. 6:247364259.

365

366

DeVRIES PJ, Murray D., Lande, R. 1997. Species diversity in vertical, horizontal, and temporal 367 dimensions of a fruit-feeding butterfly community in an Ecuadorian rainforest. Biological 368 journal of the Linnean Society, 62:343-364.

369

370 Edelman A, Gelding A, Konovalov E, Mccomiskie R, Penny A, Roberts N, Templeman S, 371 Trewin D, Ziembicki M, Trewin B, Cortlet R. 2014. State of the Tropics. James Cook 372 University. Cairns.

373

374 Ek-Amnuay P, Komaradat P. 2006. Butterflies of Thailand. Baan lae Suan, Bangkok, Thailand. 375

376 Fleishman E, Murphy DD. 2009. A realistic assessment of the indicator potential of butterflies 377 and other charismatic taxonomic groups. Conservation Biology. 23:1109-1116. 
378

379 Forister ML, McCall AC, Sanders NJ, Fordyce JA, Thorne JH, O’Brien J, Waetjen DP, Shapiro 380 381 382

AM. 2010 Compounded effects of climate change and habitat alteration shift patterns of butterfly diversity. Proceedings of the National Academy of Sciences. 107:2088-2092.

Glenner H, Thomsen PF, Hebsgaard MB, Sorensen MV, Willerslev E. 2006. Evolution: The origin of insects. Science. 314:1883-1884.

Goehring L, Oberhauser KS. 2002. Effects of photoperiod, temperature, and host plant age on induction of reproductive diapause and development time in Danaus plexippus. Ecological Entomology. 27:674-685.

Graves SD., Shapiro AM. 2003. Exotics as host plants of the California butterfly fauna. Biological conservation. 110:413-433.

Hamer KC, Hill JK, Benedick S, Mustaffa N, Sherratt TN, Maryati M. 2003. Ecology of butterflies in natural and selectively logged forests of northern Borneo: the importance of habitat heterogeneity. Journal of Applied Ecology. 40:150-162.

Hamer KC, Hill J, Mustaffa N, Benedick S, Sherratt TN, Chey VK, Maryati M. 2005. Temporal variation in abundance and diversity of butterflies in Bornean rain forests: opposite impacts of logging recorded in different seasons. Journal of tropical ecology. 21:417-425. 
401 Harvell CD, Mitchell CE, Ward JR, Altizer S, Dobson AP, Ostfeld RS, Samuel MD. 2002.

402 Climate warming and disease risks for terrestrial and marine biota. Science. 296:2158-2162.

403

404 Hill JK, Collingham YC, Thomas CD, Blakeley DS, Fox R, Moss D, Huntley B. 2001. Impacts 405 of landscape structure on butterfly range expansion. Ecology Letters. 4:313-321. 406

407 IUCN Bangladesh. 2015. Red List of Bangladesh Volume 7: Butterflies. IUCN, International 408 Union for Conservation of Nature, Bangladesh Country Office, Dhaka, Bangladesh. 409

410 Kehimkar ID. 2008. The Book of Indian butterflies. Bombay Natural History Society; Oxford $411 \quad$ University Press.

412

413 Khan MK. 2014. Three new records of butterfly from university of Chittagong and Shahjalal 414 University of science and technology in Bangladesh. International Journal of Fauna and $415 \quad$ Biological Studies. 1:30-33.

416

417 Khandokar F, Rashid M, Das DK, Hossain M. 2013. Species diversity and abundance of 418 Butterflies in the Lawachara National Park, Bangladesh. Jahangirnagar University Journal 419 of Biological Science. 2:121-127.

420

421 Larsen TB. 2004. Butterflies of Bangladesh: an annotated checklist. IUCN, Bangladesh. 422 
423 Lewis OT, Senior MJ. 2011. Assessing conservation status and trends for the world's butterflies:

424 the Sampled Red List Index approach. Journal of Insect Conservation. 151:121-128.

425

426 Lu GY, Wong DW. 2008. An adaptive inverse-distance weighting spatial interpolation $427 \quad$ technique. Computers \& Geosciences. 34:1044-1055.

428

429 Matteson KC, Taron DJ, Minor ES. 2012. Assessing citizen contributions to butterfly monitoring 430 in two large cities. Conservation Biology. 26:557-564.

431

432 McKinney ML. 2002. Influence of settlement time, human population, park shape and age, 433 visitation and roads on the number of alien plant species in protected areas in the USA. $434 \quad$ Diversity and distributions. 8:311-318.

435

436 McKinney ML. 2008. Effects of urbanization on species richness: a review of plants and 437 animals. Urban ecosystems. 11:161-176.

\section{8}

439 McIntyre NE. 2000. Ecology of urban arthropods: a review and a call to action. Annals of the $440 \quad$ Entomological Society of America. 93:825-835.

441

442 New TR. 1997. Are Lepidoptera an effective 'umbrella group' for biodiversity Conservation? $443 \quad$ Journal of Insect Conservation. 1:5-12.

444 
445 Pekar S, Brabec M. 2016. Modern Analysis of Biological Data - Generalised Linear Models in 446 R. Muni Press.

447

448 Pickett STA, Cadenasso ML, Grove JM, Boone CG, Groffman PM, Irwin E, Kaushal SS, 449 Marshall V, Mcgrath BP, Nilon CH, Pouyat RV, Szlavecz K, Troy A, Warren P. 2011.

$450 \quad$ Urban ecological systems: Scientific foundations and a decade of progress. Journal of $451 \quad$ Environmental Management. 92:331-362.

452

453 Proctor M, Yeo P. and Lack A. 1996. The natural history of pollination. Harper Collins $454 \quad$ Publishers.

455

456 Proença V, Martin LJ, Pereira HM, Fernandez M, Mcrae L, Belnap J, Böhm M, Brummitt N, 457 García-Moreno J, Gregory RD, Honrado JP. 2016. Global biodiversity monitoring: From 458 data sources to Essential Biodiversity Variables. Biological Conservation. xxx-xxx.

459

460 van der Putten WH, Macel M, Visser ME. 2010. Predicting species distribution and abundance 461 responses to climate change: why it is essential to include biotic interactions across trophic 462 levels. Philosophical Transactions of the Royal Society of London B: Biological Sciences. $463 \quad 365: 2025-2034$.

464

465 Rader R, Bartomeus I, Garibaldi LA, Garratt MP, Howlett BG, Winfree R, Bommarco R. 2016. 466 Non-bee insects are important contributors to global crop pollination. Proceedings of the $467 \quad$ National Academy of Sciences. 113:146-151. 
468

469 Raupp MJ, Shrewsbury PM, Herms DA. 2010. Ecology of herbivorous arthropods in urban $470 \quad$ landscapes. Annual review of entomology. 55:19-38.

471

472 R Core Team. 2014. R: A language and environment for statistical computing. R Foundation for $473 \quad$ Statistical Computing, Vienna, Austria.

474

475 Recuero E, Cruzado-Cortes J, Parra-Olea G, Zamudio KR, Kelly R. 2010. Urban aquatic habitats 476 and conservation of highly endangered species: the case of Ambystoma mexicanum 477 (Caudata, Ambystomatidae). Annales Zoologici Fennici. 47:223-238.

478

479

480

481

482

483

484

485

486

487

488

489 490

Reeder NMM, Byrnes RM, Stoelting RE, Swaim KE. 2015. An endangered snake thrives in a highly urbanized environment. Endangered Species Research. 28:77-86.

Rickman JK, Connor EF. 2003. The effect of urbanization on the quality of remnant habitats for leaf-mining Lepidoptera on Quercus agrifolia. Ecography. 26:777-787.

Ricketts TH, Daily GC, Ehrlich PR. 2002. Does butterfly diversity predict moth diversity?. Testing a popular indicator taxon at local scales. Biological Conservation. 103:361-370. 
491 Scheffers BR, Joppa LN, Pimm SL, Laurance WF. 2012. What we know and don't know about 492 Earth's missing biodiversity. Trends in ecology \& evolution. 27:501-510.

493

494 Schipper J, Chanson JS, Chiozza F, Cox NA, Hoffmann M, Katariya V, Lamoreux J, Rodrigues

495 AS, Stuart SN, Temple HJ, Baillie J. 2008. The status of the world's land and marine 496 mammals: diversity, threat, and knowledge. Science. 322:225-230.

497

498 Shapiro, Arthur M. 2002. The Californian urban butterfly fauna is dependent on alien plants.

499 Diversity and Distributions. 8:31-40.

500

501 Sibatani A. 1990. Decline and conservation of butterflies in Japan. Journal of Research on the $502 \quad$ Lepidoptera. 29:305-315.

503

504 Smallidge PJ, Leopold DJ, Allen CM. 1996. Community characteristics and vegetation 505 management of Karner blue butterfly (Lycaeides melissa samuelis) habitats on rights-of506 way in east-central New York, USA. Journal of Applied Ecology. 33:1405-1419.

507

508 Stefanescu C, Herrando S, Páramo F. 2004. Butterfly species richness in the north-west 509 Mediterranean Basin: the role of natural and human-induced factors. Journal of $510 \quad$ Biogeography. 31:905-915.

511

512 Thomas R, Vaughan I, Lello J. 2013. Data Analysis with R Statistical Software. Eco-explore. 513 
514 Thomas JA. 2005. Monitoring change in the abundance and distribution of insects using 515 butterflies and other indicator groups. Philosophical Transactions of the Royal Society of $516 \quad$ London B: Biological Science. 360:339-357.

517

518 Tittensor DP, Walpole M, Hill SL, Boyce DG, Britten GL, Burgess ND, Butchart SH, Leadley 519 PW, Regan EC, Alkemade R, Baumung R. 2014. A mid-term analysis of progress toward 520 international biodiversity targets. Science. 346:241-244.

521 
522 Figure 1. Map of the University of Dhaka campus (Adapted from a map, created by Department 523 of Geography, University of Dhaka)

524 Figure 2. Bar graph, showing weekly butterfly species richness

525 Figure 3. Scatter plots showing the relationship of various abiotic factors to butterfly species 526 richness

527 Figure 4. Map of the University of Dhaka campus showing measured (a) and predicted (b) 528 species richness of butterflies using the inverse distance weight interpolation. 
Figure 1. Map of the University of Dhaka campus (Adapted from a map, created by Department of Geography, University of Dhaka)

$$
1851 \times 1306 \mathrm{~mm}(96 \times 96 \mathrm{DPI})
$$




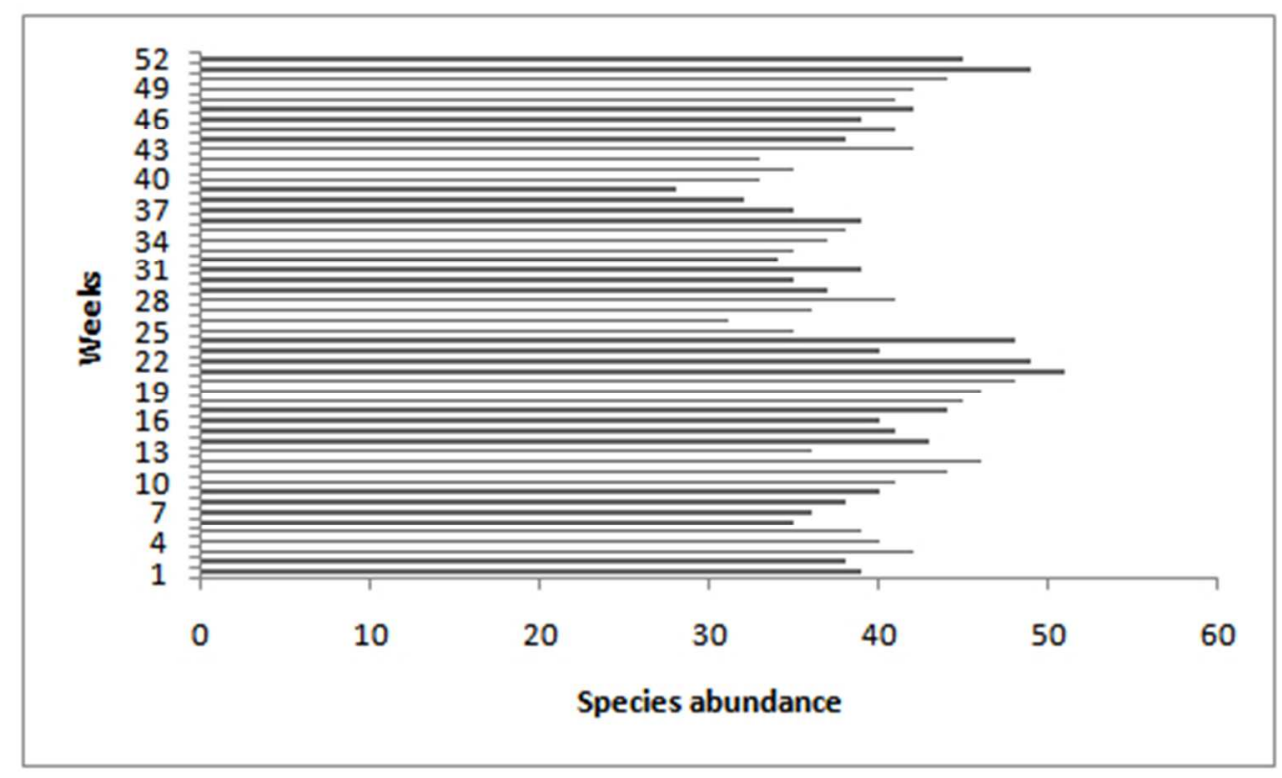

Figure 2. Weekly butterfly species richness at the University of Dhaka campus $41 \times 25 \mathrm{~mm}(300 \times 300 \mathrm{DPI})$ 
1

2

3

4

5

6

7

8

9

10

11

12

13

14

15

16

17

18

19

20

21

22

23

24

25

26

27

28

29

30

31

32

33

34

35

36

37

38

39

40

41

42

43

44

45

46

47

48

49

50

51

52

53

54

55

56

57

58

59

60

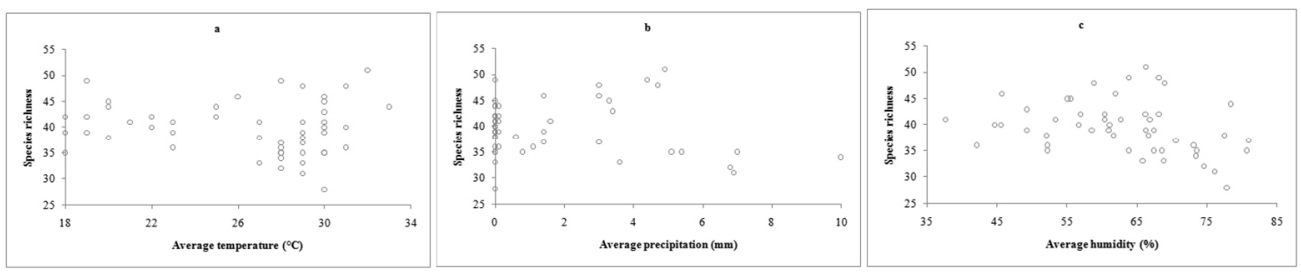

Figure 3. The relationship of abiotic factors to butterfly species richness.

$1371 \times 286 \mathrm{~mm}(96 \times 96$ DPI) 

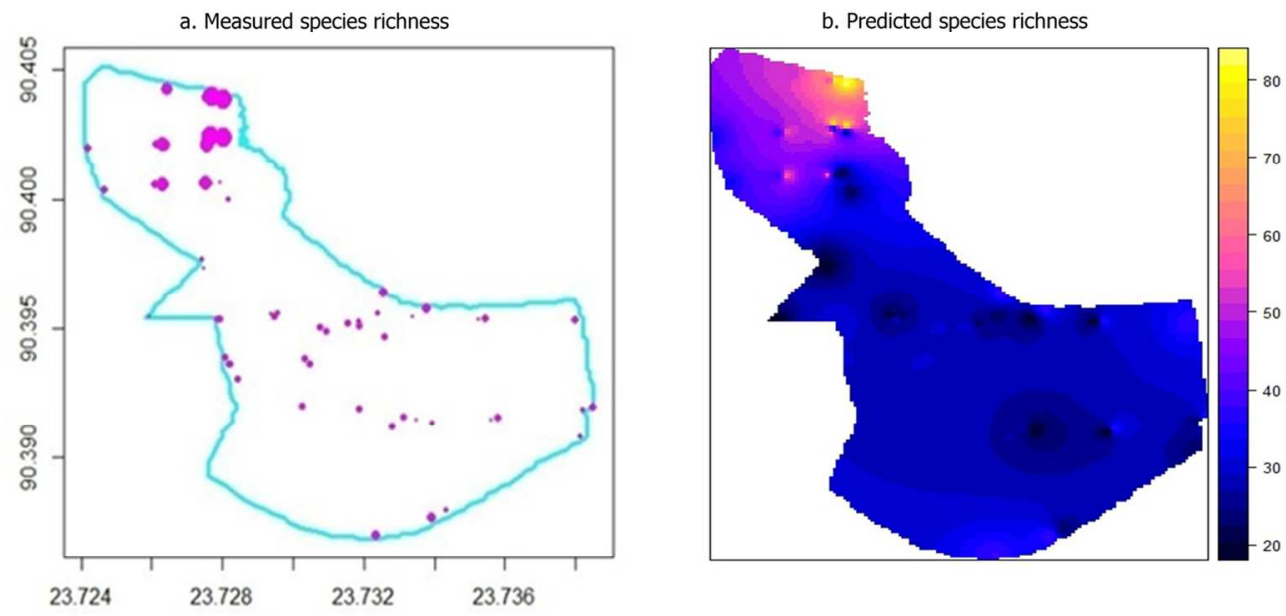

Figure 4. Map of the University of Dhaka campus showing species richness of butterflies using the inverse distance weight interpolation

$58 \times 35 \mathrm{~mm}(600 \times 600$ DPI $)$ 
Table-1: Observed butterfly species and their national red list assessment status

\begin{tabular}{|c|c|c|c|c|}
\hline Family & Subfamily & Scientific Name & $\begin{array}{l}\text { Author and } \\
\text { Published Year }\end{array}$ & $\begin{array}{l}\text { IUCN Red } \\
\text { List } \\
\text { Category in } \\
\text { Bangladesh } \\
\text { National } \\
\text { Red List }\end{array}$ \\
\hline \multirow[t]{13}{*}{ Pieridae } & \multirow[t]{5}{*}{ Colia } & Eurema andersoni & (Moore, 1886) & $\mathrm{LC}$ \\
\hline & & Eurema hecabe & (Linnaeus, 1758) & $\mathrm{LC}$ \\
\hline & & Eurema blanda & (Boisduval, 1836) & $\mathrm{LC}$ \\
\hline & & Catopsilia pomona & (Fabricius, 1775) & $\mathrm{LC}$ \\
\hline & & Catopsilia pyranthe & (Linnaeus, 1758) & $\mathrm{LC}$ \\
\hline & \multirow[t]{8}{*}{ Pierinae } & Cepora nerissa & (Fabricius, 1775) & $\mathrm{LC}$ \\
\hline & & Appias libythea & (Fabricius, 1775) & $\mathrm{LC}$ \\
\hline & & Appias lyncida & (Cramer, 1777) & $\mathrm{LC}$ \\
\hline & & Hebomoia glaucippe & (Linnaeus, 1758) & VU \\
\hline & & Pieris canidia & (Linnaeus, 1768) & $\mathrm{LC}$ \\
\hline & & Delias eucharis & (Drury, 1773) & $\mathrm{LC}$ \\
\hline & & Delias descombesi & (Boisduval, 1836) & $\mathrm{LC}$ \\
\hline & & Leptosia nina & (Fabricius, 1793) & $\mathrm{LC}$ \\
\hline \multirow{7}{*}{$\begin{array}{l}\text { Lycaenida } \\
\mathrm{e}\end{array}$} & \multirow{7}{*}{$\begin{array}{l}\text { Polyommati } \\
\text { nae }\end{array}$} & Zizula hylax & (Fabricius, 1775) & $\mathrm{LC}$ \\
\hline & & Pseudozizeeriamaha & (Kollar, 1844) & $\mathrm{LC}$ \\
\hline & & Zizina otis & (Fabricius, 1787) & $\mathrm{LC}$ \\
\hline & & Zizeeria karsandra & (Moore, 1865) & $\mathrm{LC}$ \\
\hline & & Jamides celeno & (Cramer, 1775) & $\mathrm{LC}$ \\
\hline & & Jamides alecto & (Felder, 1860) & $\mathrm{LC}$ \\
\hline & & Chilades pandava & (Horsfield, 1829) & $\mathrm{LC}$ \\
\hline
\end{tabular}




\begin{tabular}{|c|c|c|c|c|}
\hline & & Chilades contracta & (Butler, 1880) & $\mathrm{EN}$ \\
\hline & & Chilades lajus & (Stoll, 1780) & $\mathrm{LC}$ \\
\hline & & Euchrysops cnejus & (Fabricius, 1798) & $\mathrm{LC}$ \\
\hline & & Lampides boeticus & (Linnaeus, 1767) & $\mathrm{LC}$ \\
\hline & & Catochrysops strabo & (Fabricius, 1793) & VU \\
\hline & & Anthene lycaenina & (Felder, 1868) & $\mathrm{EN}$ \\
\hline & & Leptotes plinius & (Fabricius, 1793) & $\mathrm{LC}$ \\
\hline & & Castalius rosimon & (Fabricius, 1775) & $\mathrm{LC}$ \\
\hline & & Tarucus venosus & (Moore, 1882) & NA \\
\hline & & Tarucus nara & (Kollar, 1848) & $\mathrm{EN}$ \\
\hline & & Tarucus callinara & (Butler, 1886) & $\mathrm{EN}$ \\
\hline & & Prosotas nora & (Felder, 1860) & $\mathrm{LC}$ \\
\hline & & Prosotas dubiosa & (Semper, 1879) & VU \\
\hline & & $\begin{array}{l}\text { Neopithecops } \\
\text { zalmora }\end{array}$ & (Butler, 1870) & $\mathrm{LC}$ \\
\hline & Theclinae & Rapala manea & (Hewitson, 1863) & $\mathrm{LC}$ \\
\hline & & Rathinda amor & (Fabricius, 1775) & VU \\
\hline & & Remelana jangala & (Horsfield, 1829) & VU \\
\hline & Curetinae & Curetis thetis & (Drury, 1773) & $\mathrm{LC}$ \\
\hline & Miletinae & Spalgis epius & (Westwood, 1852) & $\mathrm{EN}$ \\
\hline Nymphali & Nymphalina & Junonia almanac & (Linnaeus, 1758) & $\mathrm{LC}$ \\
\hline & & Junonia hierta & (Fabricius, 1798) & $\mathrm{LC}$ \\
\hline & & Junonia lemonias & (Linnaeus, 1758) & $\mathrm{LC}$ \\
\hline & & Junonia atlites & (Linnaeus, 1763) & $\mathrm{LC}$ \\
\hline & & Junonia orithya & (Linnaeus, 1758) & $\mathrm{VU}$ \\
\hline & & Vanessa cardui & (Linnaeus, 1758) & $\mathrm{EN}$ \\
\hline & & Hypolimnas bolina & (Linnaeus, 1758) & $\mathrm{LC}$ \\
\hline
\end{tabular}




\begin{tabular}{|c|c|c|c|c|}
\hline & & Hypolimnas misippus & (Linnaeus, 1764) & $\overline{\mathrm{VU}}$ \\
\hline & Limenitidin & Neptis hylas & (Linnaeus, 1758) & $\mathrm{LC}$ \\
\hline & & Neptis jumbah & (Moore, 1858) & $\mathrm{LC}$ \\
\hline & & Athyma perius & (Linnaeus, 1758) & $\mathrm{LC}$ \\
\hline & & Moduza procris & (Cramer, 1777) & $\mathrm{LC}$ \\
\hline & & Euthalia aconthea & (Cramer, 1777) & $\mathrm{LC}$ \\
\hline & Heliconiina & Cethosia cyane & (Drury, 1773) & $\mathrm{LC}$ \\
\hline & & Acraea violae & (Fabricius, 1793) & $\mathrm{LC}$ \\
\hline & & Phalanta phalantha & (Drury, 1773) & $\mathrm{LC}$ \\
\hline & Biblidinae & Ariadne merione & (Cramer, 1777) & $\mathrm{LC}$ \\
\hline & & Ariadne ariadne & (Linnaeus, 1763) & $\mathrm{LC}$ \\
\hline & Danainae & Danaus chrysippus & (Linnaeus, 1758) & $\mathrm{LC}$ \\
\hline & & Danaus genutia & (Cramer, 1779) & $\mathrm{LC}$ \\
\hline & & Tirumala limniace & (Cramer, 1775) & $\mathrm{LC}$ \\
\hline & & Euploea core & (Cramer, 1780) & $\mathrm{LC}$ \\
\hline & Satyrinae & $\begin{array}{l}\text { Elymnias } \\
\text { hypermnestra }\end{array}$ & (Linnaeus, 1763) & $\mathrm{LC}$ \\
\hline & & Mycalesis perseus & (Fabricius, 1775) & $\mathrm{VU}$ \\
\hline & & Mycalesis mineus & (Linnaeus, 1758) & $\mathrm{LC}$ \\
\hline & & Melanitis leda & (Linnaeus, 1758) & $\mathrm{LC}$ \\
\hline & & Melanitis phedima & (Cramer, 1780) & $\mathrm{VU}$ \\
\hline & & Lethe europa & (Fabricius, 1775) & $\mathrm{VU}$ \\
\hline Hesperiida & Hesperiinae & Cephrenes acalle & (Hopffer, 1874) & $\mathrm{VU}$ \\
\hline & & Telicota ancilla & $\begin{array}{l}\text { (Herrich-Schäffer, } \\
1869 \text { ) }\end{array}$ & $\mathrm{VU}$ \\
\hline & & Telicota colon & (Fabricius, 1775) & $\mathrm{LC}$ \\
\hline & & Oriens goloides & (Moore, 1881) & $\mathrm{VU}$ \\
\hline
\end{tabular}




\begin{tabular}{|c|c|c|c|c|}
\hline & & Oriens gola & (Moore, 1877) & $\mathrm{LC}$ \\
\hline & & Pelopidas agna & (Moore, 1866) & $\mathrm{LC}$ \\
\hline & & Pelopidas conjunctus & $\begin{array}{l}\text { (Herrich-Schäffer, } \\
1869 \text { ) }\end{array}$ & $\mathrm{LC}$ \\
\hline & & Pelopidas sinensis & (Mabille, 1877) & NA \\
\hline & & Pelopidas mathias & (Fabricius, 1798) & VU \\
\hline & & Borbo cinnara & (Wallace, 1866) & $\mathrm{LC}$ \\
\hline & & Suastus gremius & (Fabricius, 1798) & $\mathrm{EN}$ \\
\hline & & Parnara bada & (Moore, 1878) & $\mathrm{EN}$ \\
\hline & & Parnara guttatus & $\begin{array}{l}\text { (Bremer \& Grey, } \\
1852)\end{array}$ & $\mathrm{LC}$ \\
\hline & & Parnara ganga & Evans, 1937 & NA \\
\hline & & Udaspes folus & (Cramer, 1775) & $\mathrm{LC}$ \\
\hline & & Hyarotis adrastus & (Stoll, 1780) & VU \\
\hline & & Matapa aria & (Moore, 1866) & $\mathrm{LC}$ \\
\hline & Coeliadinae & $\begin{array}{l}\text { Badamia } \\
\text { exclamationis }\end{array}$ & (Fabricius, 1775) & VU \\
\hline & & Hasora chromus & (Cramer, 1780) & $\mathrm{EN}$ \\
\hline Papilionid & Papilioninae & Papilio polytes & (Linnaeus, 1758) & $\mathrm{LC}$ \\
\hline & & $\begin{array}{l}\text { Atrophaneura } \\
\text { aristolochiae }\end{array}$ & (Fabricius, 1775) & $\mathrm{LC}$ \\
\hline & & Atrophaneura hector & (Linnaeus, 1758) & $\mathrm{EN}$ \\
\hline & & Papilio clytia & (Linnaeus, 1758) & $\mathrm{LC}$ \\
\hline & & Papilio demoleus & (Linnaeus, 1758) & $\mathrm{LC}$ \\
\hline & & Graphium doson & (Felder, 1864) & $\mathrm{LC}$ \\
\hline & & $\begin{array}{l}\text { Graphium } \\
\text { agamemnon }\end{array}$ & (Linnaeus, 1758) & $\mathrm{LC}$ \\
\hline
\end{tabular}

